\title{
Changes in the Estrous Cycle and Number of Ovulated and Fertilized Ova in Aging Female NCS Mice
}

\author{
Baharuddin TAPPA **, Hiromi AMAO, Akira OGASA *, and \\ Kazuaki W. TAKAHASHI \\ Department of Laboratory Animal Science, ${ }^{*}$ Department of Veterinary Clinical \\ Reproduction, Nippon Veterinary and Zootechnical College, \\ Kyonan-cho 1-7-1, Musashino-shi, Tokyo 180, Japan
}

(Received 17 June 1988/ Accepted 9 November 1988)

\begin{abstract}
N CS mice (ddN origin) aged 90 days (control) and 180, 210, 240, 270, 300, 330, 360 and 420 days were used for observation of the length of the estrous cycle, and the numbers of ovulated and fertilized ova. The estrous cycle between the ages of 90 and 330 days presented a regular 4-day pattern. Thereafter, regularity of the cycle declined steadily between the ages of 360 and 420 days. All mice over 420 days old exhibited cessation of cyclicity and ultimately persistent diestrus. The average number of ova ovulated in mice aged between 90 and 240 days was consistent ( 11.8 to 11.4 ova), whereas a steady decline was observed for mice between 270 days old (10.5 ova) and 360 days old (4.8 ova). Ova were not recovered from oviducts of mice aged about 420 days. The average number of fertilized ova (2-cell stage) in mice between 90 and 210 days old showed no significant change(11.5 to 10.3), whereas the number began to decrease in mice aged between 240 days ( 8.7 fertilized ova) and 330 days ( 2.5 fertilized ova). No fertilized ova were recovered from the oviducts of mice around 360 days old. These findings demonstrate that the decline of reproductive activity is initially observed in the number of fertilized ova, followed by a decline in the number of ovulations and finally by loss of the estrous cycle.
\end{abstract}

A decline in reproductive activity with increasing age has been demonstrated in female mammals, such as rats $[12,13]$, hamsters [2 $\sim 4,20]$ and mice $[1,7,11]$. Aging female mice exhibit a progressive decrease in their ability to maintain the regular length of estrous cycles, vaginal cytology [16], and normal endocrine and ovarian function [6]. Generally, beginning in middle age, many females display prolonged cycles instead of regular cyclicity. Shortly thereafter, aging females show persistent diestrus. Concomitant with these conditions, an increasing number of aging mice become infertile, and among the fertile females the ovulation rate and fertilization rate decrease markedly.

Since NCS mice show a regular 4--day estrous cycle [17], many studies on reproduc- tive physiology have been done using this strain. However, there have been almost no detailed reports concerning the influence of aging on fertility.

This study was undertaken to examine the changes in the estrous cycles patterns and number of ovulation or fertilized eggs during aging in virgin $\mathrm{N} C S$ mice.

\section{Materials and Methods}

Animals : Male and female mice of the $\mathrm{N}$ CS strain (ddN origin) were used. The females were divided into the following groups : 90 days old (control), and 180, 210, 240, 270, 300, 330,360 and 420 days old ( $n=6$ mice/group). Animals that had shown more than two regular 4-day estrous cycles were used, except for the

${ }^{* *}$ Center for Research and Development in Biology, Indonesian Institute of Sciences, Jalan Raya Juanda 18, Bogor 16122, Indonesia 
420-day-old group. The males used were 120150 days old.

Raising environment and condition : The animals were raised at a room temperature of $20-25^{\circ} \mathrm{C}$ with a relative humidity of $40-70 \%$.

They had artificial illumination for 14 daily from $05: 00$ to $19: 00$ and were housed in groups of 5-6 animals in aluminum cages (W221 $\times$ D $330 \times \mathrm{H} 180 \mathrm{~mm}$ ) with wooden shavings placed on a wire net floor. They were allowed a standard laboratory pellet (CA-1 of the CLEA JAPAN, INC.) and tap-water ad libitum.

Vaginal smears and estrous cycles : Estrous cycles were checked using vaginal smears obtained daily between $09: 00$ and 10:00. The smears were classified according to Nobunaga et al. [17] : proestrus ( I ), estrus ( III), metestrus $(N)$ and diestrus (V). Females that had exhibited at least two consecutive 4-day cycles were considered to have a regular cycle. Those with prolonged cycles ( $5 \sim 12$ days duration) were classified as having irregular cycles.

Ovulation and fertilization rate : To determine the number of ovulations, female mice that had shown more than two regular 4-day estrous cycles were killed between $10: 00$ and $12: 00 \mathrm{~h}$ on the day of their estrous stage ( III). Oviducts were exposed, ova were recovered by cutting the ampulla region under a dissecting microscope (Olympus SZ, Tokyo), and the numbers of ova were counted. To observe the number of fertilized ova, both regularly and irregularly cyclic mice were mated with normal males and shecked for vaginal plugs (Day 0 of pregnancy) between $09: 00$ and $10: 00 \mathrm{~h}$ the next morning. Females were killed between 10 $: 00$ and $12: 00 \mathrm{~h}$ on Day 1 of pregnancy. Both uterine horns and oviducts were exposed and fertilized ova were recovered by flushing the oviducts with Whittingham's medium [21] into a watch-glass under a dissecting microscope. Ova were classified as fertilized when they were at the 2-cell stage, whereas one-cell and fragmented ova were classified as abnormal or unfertilized. Reproductive organs such as the uterus, ovaries, adrenal and pituitary glands were weighed with a torsion balance and fixed in $10 \%$ formalin.

Differences between means were tested statistically by Student's $t$ test.

\section{Results}

1. Estrous cycles: The patterns of estrous cycles in the 4-day-cycle NCS mice varied according to age (Fig. 1). All of the virgin females from 90 to 330 days of age showed a regular 4-day estrous cycle. Incidence of regular cycles decreased significantly in 360 - to $420^{-}$ day-old females. All mice over 420 days old presented no cycles and became persistently diestrous.

2. Ovulation rate: The average numbers of ova and fertilized ova are shown in Table 1. The average number of ova recovered was consistent for females between 90 and 300 days old, whereas for those between 330 and 360 days old a marked decline was observed. Ova were not recovered from oviducts of 420-days-old mice.

3. Fertilization rate: The average number of fertilized ova collected from oviducts of mice aged between 90 and 210 days was consistent, whereas it began to decrease with increasing age between 240 and 330 days. No fertilized ova were recovered from the oviducts of 360 - and 420-day-old females. The number of unfertilized ova increased with age. Mice aged 240360 days had a significantly larger number of unfertilized ova as compared with that of $90-$ day-old mice ( $p<0.05, \quad p<0.001)$.

4. Body weight and reproductive organ weight : The average body weight, and the weights of the uterus, ovaries, pituitary and adrenal

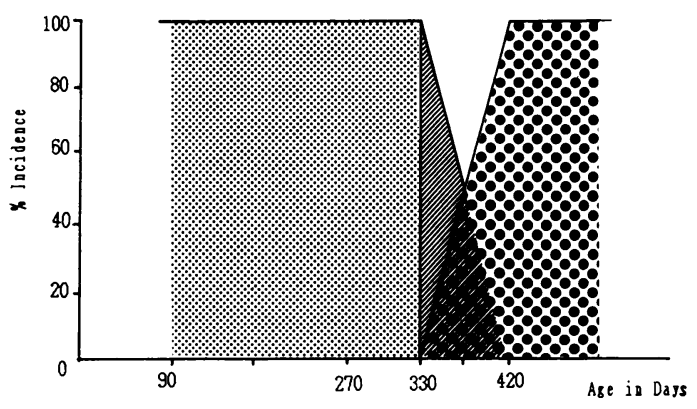

Fig. 1. Changes in estrous cycles with increasing age in NCS mice ( $n=6$ mice/group) : Regular 4-day estrous cycle $\mathbb{W}$ : Irregular estrous cycle : Persistent diestrus 
Table 1. The numbers of ovulations, fertilized ova and unfertilized ova at different ages ir. female N CS mice

\begin{tabular}{rcccc}
\hline \multirow{2}{*}{$\begin{array}{c}\text { Age } \\
\text { (days) }\end{array}$} & $\begin{array}{c}\text { No. of } \\
\text { females }\end{array}$ & Total & \multicolumn{3}{c}{$\begin{array}{c}\text { Fumber of ova } \\
\text { (2-cell) }\end{array}$} & $\begin{array}{c}\text { Unfertilized or } \\
\text { abnormal }\end{array}$ \\
\hline 90 & 6 & $11.8 \pm 0.5^{\text {a) }}$ & $11.5 \pm 0.4$ & $0.3 \pm 0.2$ \\
180 & 6 & $11.4 \pm 1.6$ & $11.0 \pm 0.7$ & $0.4 \pm 0.2$ \\
210 & 6 & $11.7 \pm 0.5$ & $10.3 \pm 0.7$ & $1.4 \pm 0.7$ \\
240 & 6 & $11.4 \pm 1.0$ & $8.7 \pm 0.9^{* *}$ & $2.7 \pm 0.5^{*}$ \\
270 & 6 & $10.5 \pm 1.2$ & $6.7 \pm 0.9^{* * *}$ & $3.8 \pm 1.2^{* * *}$ \\
300 & 6 & $10.2 \pm 1.2$ & $5.5 \pm 0.6^{* * *}$ & $4.7 \pm 1.1^{* * *}$ \\
330 & 6 & $6.0 \pm 0.8^{* * *}$ & $25 \pm 1.9^{* * *}$ & $3.5 \pm 0.5^{* * *}$ \\
360 & 6 & $4.8 \pm 0.5^{* * *}$ & 0 & $4.8 \pm 0.5^{* * *}$ \\
420 & 6 & 0 & 0 & 0 \\
\hline
\end{tabular}

a) Means \pm S.E. $\quad$ * Significantly different from 90 days at

$\mathrm{p}<0.05 * * *$ Significantly different from 90 days at

$\mathrm{p}<0.01 \quad * * *$ Significantly different from 90 days at

$\mathrm{p}<0.001$

Table 2. Weights of reproductive organs at different ages in female NCS mice

\begin{tabular}{ccccccc}
\hline \multirow{2}{*}{$\begin{array}{c}\text { Age } \\
\text { (days) }\end{array}$} & $\begin{array}{c}\text { No. of } \\
\text { females }\end{array}$ & $\begin{array}{c}\text { Body weight } \\
(\mathrm{g})\end{array}$ & \multicolumn{4}{c}{ Reproductive organ weight $(\mathrm{mg})$} \\
\cline { 4 - 7 } & & \multicolumn{1}{c}{ Uterus } & Ovaries & Pituitary & Adrenals \\
\hline 90 & 6 & $26.9 \pm 0.6^{\text {a) }}$ & $120.4 \pm 5.1$ & $12.4 \pm 1.6$ & $4.2 \pm 0.8$ & $17.5 \pm 1.1$ \\
180 & 6 & $28.5 \pm 0.7$ & $132.1 \pm 2.6$ & $13.6 \pm 0.8$ & $4.1 \pm 0.4$ & $16.3 \pm 0.1$ \\
210 & 6 & $29.6 \pm 0.6^{* *}$ & $134.4 \pm 9.0$ & $14.5 \pm 0.2$ & $4.1 \pm 0.2$ & $14.9 \pm 0.8$ \\
240 & 6 & $29.6 \pm 0.9^{* *}$ & $170.2 \pm 1.5^{* * *}$ & $14.6 \pm 0.3$ & $4.1 \pm 0.2$ & $14.3 \pm 0.3^{*}$ \\
270 & 6 & $31.2 \pm 1.4^{* *}$ & $181.3 \pm 1.1^{* * *}$ & $14.9 \pm 0.3^{*}$ & $4.0 \pm 0.2$ & $13.9 \pm 0.9^{*}$ \\
300 & 6 & $32.1 \pm 0.7^{* * *}$ & $201.4 \pm 1.2^{* * *}$ & $15.6 \pm 1.4^{*}$ & $4.0 \pm 0.3$ & $13.8 \pm 0.7^{*}$ \\
330 & 6 & $32.5 \pm 1.4^{* * *}$ & $223.5 \pm 2.5^{* * *}$ & $15.8 \pm 1.2^{*}$ & $3.9 \pm 0.3$ & $13.4 \pm 1.4^{*}$ \\
360 & 6 & $32.6 \pm 0.8^{* * *}$ & $321.3 \pm 2.1^{* * *}$ & $15.9 \pm 1.1^{* *}$ & $3.7 \pm 0.1$ & $12.5 \pm 1.1^{* *}$ \\
420 & 6 & $34.2 \pm 1.2^{* * *}$ & $422.2 \pm 1.5^{* * *}$ & $16.9 \pm 0.7^{* *}$ & $3.4 \pm 0.3$ & $12.4 \pm 0.8^{* *}$ \\
\hline
\end{tabular}

a) Means \pm S. E. $\quad *$ Significantly different from 90 days at $\mathrm{p}<0.05$ $* *$ Significantly different from 90 days at $\mathrm{p}<0.01 \quad * * *$ Significantly different from 90 days at $\mathrm{p}<0.001$

glands of female mice are shown in Table 2. The average body weight, and uterine and ovarian weight increased with aging. In contrast, pituitary and adrenal gland weights decreased with aging.

\section{Discussion}

The present results demonstrate that regular estrous cycles in NCS mice continue until the age of about 330 days and then gradually lose their regular cyclicity toward 420 days old, after which the cycle ceases completely. These results are similar to those in the previcus report of Nobunaga et al. for NCS mice [17] and also, with those previously described in other mouse strains : C $57 \mathrm{BL} / 6$ [18] ; C 57
$\mathrm{BL} / 6 \mathrm{~J}[5,16]$. The increased incidence of abnormal estrous cycles in aging mice may indicate changes in ovarian function, particularly in the secretion of estradiol $[6,14]$. In NCS mice, the cessation of cyclicity is followed by anestrus or persistent diestrus, which is characterized by a moderate to low density of leukocytes, but in other strains such as C 57 $\mathrm{BL} / 6 \mathrm{~J}$ mice, the cessation of cyclicity is followed by a pattern of prolonged estrus, which is associated with a period of persistent vaginal cornification characterized by polyfollicular ovaries, an absence of corpora lutea and moderate levels of estradiol [5, 12, 15]. Other reports of studies using the same strain indicate that plasma estradiol and progesterone levels were low and that plasma luteinizing 
hormone was elevated [8], and the ovary was apparently depleted of follicles [9] .

This study showed that the numbers of ova recovered from oviducts after ovulation were not significantly different between young (90180 days old) and middle-aged (210-240 days old) females. These data are in agreement with previous investigations that have shown no decrease in ovulation rate until middle age (200-280 days old) in NCS mice [17]. It was also reported that there was no significant difference in ovulation rate between young (4-7 months) and old (10-13 months) mice [ 1 , 10]. However, it appeared that ovulation rates in NCS mice decreased. markedly between the ages of 300 and 330 days. Talbert and Krohn [19] recovered fewer ovulated ova from the uteri of old mice than from young animals. In $\mathrm{C} 57 \mathrm{BL} / 6 \mathrm{~J}$ mice oocyte reserves are nearly exhausted when cyclicity ceases, and anovulatory mice have half the number of remaining oocytes of age-matched mice that are still ovulating [9].

The present study also indicated that the number of fertilized ova declines markedly with increasing age. The decline became significant at 240 days of age continued up to 330 days, and no fertilized ova were recovered from oviducts at 360 days of age. There are several possible explanations for this fertility decline : a reduction in the number of eggs shed, and also a higher frequency of abnormal ova in old mice than in young mice. There is a further possibility that the reproductive organs themselves may wear out, so that eggs cannot be fertilized or embryos cannot be carried to term. Since we did not specifically examine fertilization of these ova on Day 0 of pregnancy, further experiments will be necessary to assess whether ova from aging mice undergo degeneration before and/or after fertilization.

The authors are grateful to Prof. MasaeISODA, Department of Veterinary Pathology, Nippon Veterinary and Zootechnical College,for his advice, and Prof. Shyoso OGAWA, Department of Animal Reproduction, Meiji University, for his valuable suggestions. This study was supported by a grant from the Ministry of Education, Science and Culture, Japan.

\section{References}

[1] Biggers, J. D., Finn, C. A., and McLaren, A. (1962). Long-term reproductive performance of female mice. II. Variation of litter size with parity. $J$. Reprod. Fert., 3, 313-315.

[2] Blaha, G. C.(1964). Reproductive senescence in the female golden hamsters. Anat. Rec., 150, 405-412.

[3] Blaha, G. C. (1967). Effect of age, treatment, and method of induction on deciduomata in the golden hamster. Fert. Steril, 18, 477-485.

[4] Connors, J. T., Thorpe, L. W., and Soderwall, A. L. (1972). An analysis of preimplantation embryonic death in senescent golden hamsters. Biol Reprod. 6, 131-135.

[5] Felicio, L. S., Nelson, J. F., and Finch, C. E. (1984). Longitudinal studies of estrous cyclicity in aging C $57 \mathrm{BL} / 6 \mathrm{~J}$ mice : II. Cessation of cyclicity and the duration of persistent vaginal cornification. Biol. Reprod., 31, 446-453.

[6] Finch, D., Felicio, L., Mobbs, C., and Nelson, J. (1984). Ovarian and steroid influences on neuroendocrine aging processes in female rodents. Endoc. Rev., 5, 467-497.

[7] Finn, C. A. (1963). Reproductive capacity and litter size in mice : Effect of age and environment. $J$. Reprod. Fert., 6, 205-214.

[8] Gee, D. M., Flurkey, K., and Finch, C. E. (1983). Aging and the regulation of luteinizing hormone in C $57 \mathrm{BL} / 6 \mathrm{~J}$ mice : Impaired elevations after ovariectomy and spontaneous elevation at advanced ages. Biol. Reprod, 28, 598-607.

[9] Gosden, R. G., Laing, S. C., Felicio, L. S., Nelson, J. F., and Finch, C. E. (1983). Imminent oocyte exhaustion and reduced follicular recruitment mark the transition to acyclicity in aging mice. Biol Reprod. 28, 255-260.

[10] Harman, S. M. and Talbert, G. B. (1970). The effect of maternal age on ovulation, corpora lutea of pregnancy and implantation failure in mice. $J$. Reprod. Fert., 23, 33-39.

[11] Jones, E. C. and Krohn, P. L. (1961). Relationships between age, numbers of oocytes and fertility in virgin and multiparous mice of several strains. $J$. Endocrinol, 21, 469.

[12] Lu, K. H., Hopper, B. R., Vargo, T. M., and Yen, S. S. C. (1979). Chronological changes in sex steroid, gonadotrophin and prolactin secretion in aging female rats displaying different reproductive states. Biol Reprod, 21, 193-203.

[13] Matt, D. W., Lee, J., Sarver, P. L., Judd, H. L., and Lu, J. K. H. (1986 b). Chronological changes in fertility, fecundity and steroid hormone secretion during consecutive pregnancies in aging rats. Biol. Reprod, 34, 478-487.

[14] Mobbs, C. V., Flurkey, K., Gee, D. M., Yamamoto, K., Sinha, Y. N., and Finch, C. E. (1984). Estradiolinduced adult anovulatory syndrome in female C 57 $\mathrm{BL} / 6 \mathrm{~J}$ mice : Ovarian impairments and neuroendocrine impairments that are partially reversible and delayable by ovariectomy. Endocrinology, 115, 1653 -1662 .

[15] Nelson, J. F., Felicio, L. S., Osterburg, H. H., and Finch, C. E. (1981). Altered profiles of estradiol 
and progesterone associated with prolonged estrous cycles and persistent vaginal cornification in aging C 57 BL/6 J mice, Biol. Reprod, 24, 784-794.

[16] Nelson, J. F., Felicio, L. S., Randall, P. K., Simr.s, S., and Finch, C. E. (1982). A longitudinal study of estrous cyclicity in C $57 \mathrm{BL} / 6 \mathrm{~J}$ mice : I. Cycle frequency, length and vaginal cytology, Biol Reprod, 27, 327-339

[17] Nobunaga, T., Takahashi, K. W., and Okamoto, M. T. (1973). Establishment of the N CS-strain mouse showing a regular 4- day estrous cycle. Exp. Anim, 22, 277-287.

[18] Parkening, T. A., Collins, T. J., and Smith, E. R.
(1980). Plasma and pituitary concentrations of LH, FSH and prolactin in aged female $\mathrm{C} 57 \mathrm{BL} / 6$ mice : J. Reprod. Fert., 58, 377-385.

[19] Talbert, G. B. and Krohn, P. L. (1966). Effect of maternal age on viability of ova and uterine support of pregnancy in mice. J. Reprod. Fert., 11, 399 -406 .

[20] Thorneycraft, I. H. and Soderwall, A. L. (1969). The nature of the litter size loss in senescent hamsters. Anat. Rec., 165, 343-348.

[21] Whittingham, D. G. (1971). Culture of mouse ova. J. Reprod. Fert.,Suppl, 14, 7-21.

NCS 系雌マウスの加歯に伴う性周期, 排卵数, 受精卵数の変化について

\author{
バハルディン タッパ・沃尾弘実・小笠 晃*・高橋和明 \\ 日本獣医畜産大学実験動物学教室 \\ *日本獣医畜産大学獣医臨床繁殖学教室
}

NCS 系マウス（ddN 由来）において，90 (対照),

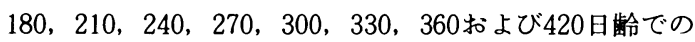
性周期, 排卵数, 受精卵数を調べた。90〜330日龄の動 物は斉一な 4 日性周期を描いていた。その後，360 - 420 日龄にかけて斉一な 4 日性周期を描く個体は減少してい った。420日齡以降は全例が発情周期を描かなくなり， 発情休止期を連続して示すようになった。平均排卯数 は，90２40日龄にかけて変化は見られず 11.4 11.8 個 であった。しかし，270日齡(10.5個）から360日齡（4.8
個）にかけて漸次減少した。そして420日龄の動物では， 卵は卵管から全く検出されなかった。卵管内の平均受精 卵数（2 細胞期）は，90〜210日龄にかけてほとんど変 化は見られず11.5〜10.3個であった。240日齡（8.7個） から330日龄（2.5個）にかけて漸次減少し，360日龄で は受精卵数 0 個となった。以上の様に, 性周期, 排卵数 および受精卵数は加齗に伴って変化し, 繁殖能力は低下 するが, 変化の開始時期では受精卵数が最も早く, 排卵 数, 性周期の順に遅くなる傾向が見られた。 